\title{
消防職員のストレス免疫能力開発に関する基礎研究 (1)
}

\author{
トレーニング・プログラムの効果測定における自由記述の分析 \\ $\bigcirc$ 菅沼憲治 ${ }^{1} \cdot$ 吉澤英里 $^{2}$ \\ $\left({ }^{1}\right.$ 聖徳大学心理・福祉学部・ ${ }^{2}$ 環太平洋大学次世代教育学部 $)$ \\ キーワード: 惨事ストレス、テキスト分析
}

Basic research on development of stress immune capacity for firefighters (1)

Kenji Suganuma $^{1}$ and Eri Yoshizawa ${ }^{2}$

$\left({ }^{1}\right.$ Faculty of Psychology and Welfare, Seitoku Univ., ${ }^{2}$ Faculty of Education for Future Generations, International Pacific Univ.)

Key Words: Critical Incident Stress, content analysis

\section{目 的}

近年、災害救助に当たる消防官が殉職したり PTSD を発症 したりしたことが報告され、消防官の惨事ストレス（Critical Incident Stress）へのケアに対する要請は増しており、消防官 のストレス耐性を高めるようなトレーニング・プログラムの 開発が急がれている。本研究の目的は、実際にプログラムを 実施し、その効果を検討することである。

\section{方 法}

参加者 東京消防庁の支援デブリーファー研修に参加した 消防官 40 名（男性 36 名、女性 2 名）のうち、2 名は実施前 のデータが収集できなかったため、38名（男性 35 名、女性 3 名)のデータを分析対象とした。平均勤続年数は 19.87 (SD 7.38）であった。

質問紙 はじめに、協力者は自然災害での救助を行ってい る写真 4 枚が提示され、このうちの 1 枚を選択した。その写 真の状況で救助を行うという状況をイメージし、「1.出勤要請 があり現場に向かう車内」、「2. 要請現場に到着し、活動中」、

「3.任務が完了して帰還する車内」、「4.職場に戻り、体験し たことを報告するために、記憶を想起して文章にまとめ上司 に報告する状況」のそれぞれについて、自由記述で回答した。 なお、回答欄には Padesky \& Mooney(1990)の認知モデルに 基づき、身体、感情、思考、行動の各項目が設けられていた。

手続き 吉澤・菅沼（印刷中）の金魚鉢方式のロールプレ イの前後で質問紙調査を実施し、記述内容の変化を比較した。

\section{結 果}

分析には KH Coder を用いた。トレーニング実施前後

(Pre・Post) と状況（1～4）をあらわす名義変数（Pre1～ Pre 4, Post1〜Post4）を作成し、記述内容の変化を検討した。

思考 文章ファイルで 2 回以上出現した 139 語を対象に、 対応分析を行った（Figure 1)。得られた情報から、移動中(1) には現場での活動をイメージしている様子が、活動後 $(3,4)$ は現場での活動を振り返っている様子が、それぞれ読み取れ た。トレーニング実施後の移動中 (Post1) は実施前 (Pre1) よりも、具体的な状況に対する不安感を示す語が布置された。

感情 95 語への対応分析を行った結果、活動後 $(3,4)$ で トレーニング前後の違いがあった。トレーニング前には肯定 的な感情 (e.g., 喜び) を表す語が近くに布置される傾向にあ ったが、トレーニング後には否定的な感情 (e.g., 無力感、残 念、疲れる）が布置されていた。

行動 140 語を対象に対応分析を行った結果、Pre3 では車 内で隊員同士のやり取りが行われている一方、会話が少なく なる者もいることがわかった。トレーニング後 (Post3) は Pre3から離れており、「ぼーっと」や「リラックス」といっ た語が近くに布置されていた。

身体 80 語を対象に対応分析を行った結果、状況の名義変
数はトレーニング前後で同じような位置に布置されていた。 全体的な傾向として、活動後（3，4）では活動中の緊張を解 く回答者がいる一方で、覚醒状態を維持している者もいた。

\section{考 察}

自由記述の内容は、移動中から活動中にかけてと、活動後 (帰署中から報告時) に分かれる傾向にあった。トレーニン グ前後の記述内容は、概ね同じような傾向を示していたが、 若干の違いが生じた。特に、思考や感情においてトレーニン グ後にネガティブな記述がよく表れるようになっていた。こ れは、トレーニングによって、よりストレスフルな状況に向 きあい、それをイメージしたり言語化したりすることができ るようになったと解釈できる。

\section{引用文献}

Padesky, C. A., \& Mooney, K. A. (1990). Presenting the cognitive model to clients. International Cognitive Therapy Newsletter, 6, 13-14.

吉澤英里・菅沼憲治 (印刷中). 消防職員のストレス免疫能力 開発に関する基礎研究(2) 日本心理学会第 81 回大会 発表 論文集.

1 本研究は学術研究助成基金助成金（挑戦的萌芽研究, 課題 番号：16K13491）の補助を受けた。

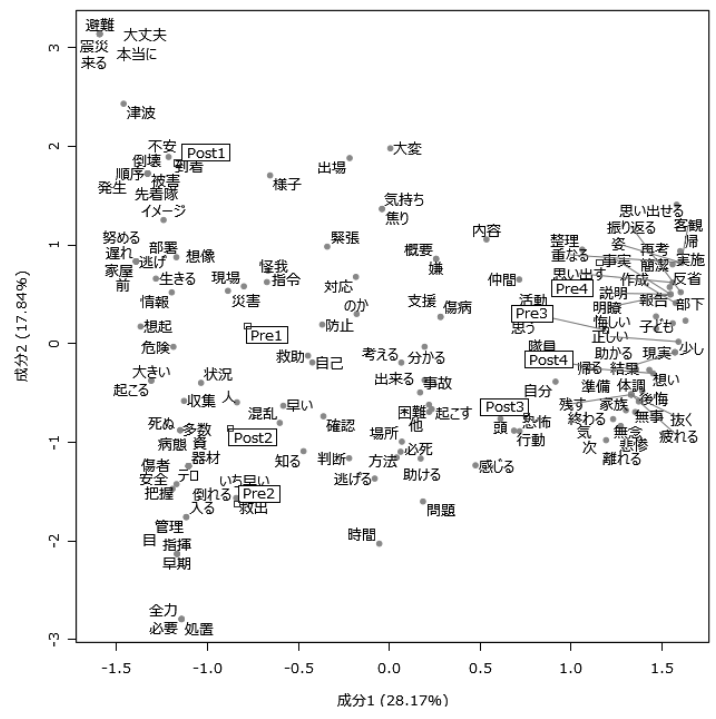

Figure 1「思考」で得られた自由回答への対応分析 